\title{
Emancipation from Violence through Global Law and Institutions : A Post-Deutschian Perspective
}

\section{Patomäki, Heikki Olavi}

Palgrave Macmillan

2019-03-14

Patomäki , H O 2019 , Emancipation from Violence through Global Law and Institutions : A Post-Deutschian Perspective . in J Kustermans, T Sauer, D Lootens \& B Segaert (eds), pÿPacifism s Appeal : Ethos, History, Politics . Rethinking Peace and Conflict Studies , Palgrave Macmillan, Cham , pp. 153-178 . https://doi.org/10.1007/978-3-030-13427-3_8

http://hdl.handle.net/10138/327964

https://doi.org/10.1007/978-3-030-13427-3_8

unspecified

acceptedVersion

Downloaded from Helda, University of Helsinki institutional repository.

This is an electronic reprint of the original article.

This reprint may differ from the original in pagination and typographic detail.

Please cite the original version. 


\title{
Emancipation from Violence through Global Law and Institutions: A Post-Deutschian
}

\section{Perspective}

\author{
Heikki Patomäki
}

\section{Introduction}

Plausible categorical, context-independent ethico-political principles are hard to come by. This applies to pacifism too, especially if it is supposed to mean the rejection of the use of physical violence to obtain any aim by any actor under any circumstances. Pacifism in this sense would for instance eliminate essential aspects of the institution of law. A possible moral aim and priority is, however, to minimize the need for any kind of violence. A position of prioritizing non-violence and seeking to minimize all forms of violence could be called pacific-ism, in contrast to straightforward pacifism (Ceadel 1987, pp. 101-165). Different dimensions of pacific-ism is best understood in terms of the ethical circle as depicted in Figure 7.1. This circle can become virtuous when actions strengthen the virtues and norms of non-violence and when the consequences of action reduce or eliminate expectations of future violence. ${ }^{1}$

\section{< Figure 7.1 about here >}

The ethical circle includes the possibility of legitimate enforcement of norms, which spawns ambiguity in the otherwise potentially virtuous circle. Even when law is not retributive, it must rely on some notion of legitimate violence. This also makes peace and progress through legal institutions somewhat problematic. We have good reasons to believe that the imposition of common laws and institutions, especially if combined with a capability of violent enforcement of norms, may well decrease rather than increase the chances of peace. In the 1950s, a group of eight scholars led by Karl Deutsch systematically studied the past experience of Germany, the Habsburg Empire, Italy, NorwaySweden, Switzerland, the United Kingdom, and the United States, to learn what history might tell us about the problem (Deutsch et al. 1957). This work has been extended to cover the latter half of the twentieth and early twenty-first century and, most importantly, the world outside the North Atlantic area. $^{2}$

From a Deutschian perspective, common institutions may aggravate the problem, but they can also be part of its solution. Deutsch and his colleagues concluded that in a security community, common social problems must and can be resolved by processes of peaceful change. By peaceful change is meant the resolution of social problems, normally by institutionalized procedures, without resort to large-scale physical force. Deutsch et.al. further distinguished between an amalgamated (centralized, 
state-like, with a strong we-identity) and pluralist (decentralized, weak common identity) security community. This suggests that the type and quality of institutions matter.

In the twenty-first century, common problems are manifold and new ones arise continuously because of complex and dynamic global and local processes in which actors and issues are tightly interwoven and spatial scales interconnected. ${ }^{3}$ As Deutsch et al. argued, it is not possible to tame or freeze history for a long time. In any given context, whether fully peaceful or not, new interests and claims will emerge and new messages demanding changes in some respects will be sent and made public (if the context allows for that) (Deutsch et al. 1957, p. 66, p. 111 etc.). Consequently, changes will be attempted, either peacefully or by means of violent enforcement. History is not going to stand still. Rather the opposite is true: nothing in history repeats itself as such. Even the best of our historical analogies are only partial; they must idealize and abstract from their source. A historical analogy is best viewed as a candidate for illuminating some essential characteristics of the geo-historical context and process under study.

Although focussing on processes and changes, Deutsch and his associates were nonetheless looking for (complex, conditional and probabilistic) regularities between variables. However, in open systems we can, at best, find only contrastive demi-regularities, which are context-bound, i.e. they are liable to change with the context. ${ }^{4}$ This raises a deeper question about what is it that could explain when and why conflicts are resolved by peaceful means and through peaceful changes? We need an account either of a mechanism or of a structured process that is transfactually efficacious across a large number of geo-historical contexts and that is independent of any particular contrastive demi-regularities between events, factors or variables.

In this chapter, I first discuss the concept of security community in some detail. Second, I outline how those common problems that need to be resolved by means of peaceful changes arise from shared processes, especially those of global political economy. Third, I explain how contradictions can be overcome through learning and building common institutions. Fourth, I argue that social contexts differ in terms of their self-transformative capacity - making them more or less open to peaceful changes - and that this capacity is closely related to the question of democracy. Actors, rules and institutions structure the processes through which common problems are tackled and resolved. A hardening will means trouble, whether constituted through the categories of nation, religion or class or something else. But actors, rules and institutions can be made more open to challenge and revision. In essence, what emerges from these considerations is a normative vision of, and an argument for, pluralism and democratic governance of the world system. However, at the end of the chapter I also explicate contingencies between self-transformative capacity, democracy and peace. Concrete utopias ${ }^{5}$ must be dynamic, reflexively critical and responsible. 


\section{The concept of security community}

Increasingly since the World War II, most political violence, and most wars, have concerned the 'inside' of states rather than been wars between sovereign states. International wars have in fact been relatively rare; only a fraction of armed conflicts are inter-state wars. Neither is a peaceful system associated exclusively with the confines of the more stable states. The security dilemma, as conventionally understood, seems to be a problem only in relations between some states (Gates, Nygård, Strand and Urdal 2016). Many groupings of states and regions have rather developed into a community within which the conventionally understood security dilemma appears irrelevant. The democratic peace hypothesis, according to which liberal-democratic states do not fight each other, covers some but not all of these actual and possible security communities.

These general characterizations were especially true in the aftermath of the end of the Cold War. They continue to hold in 2018, although (i) the world has gradually been reverting to nationalist statism, militarized conflicts and arms races especially since the global financial crisis of 2008-9 (Patomäki 2018, and although (ii) in the 2010s we have seen an upward trend in the number of fatalities incurred by organized violence. ${ }^{6}$ Most wars remain intrastate and there are no on-going inter-state wars. Moreover, most inter-state relations are not characterized by a security dilemma. The concept of security community ${ }^{7}$ can explain why, in particular but possibly long-standing geo-historical contexts, wars are more common within states than between them. ${ }^{8}$ The concept is applicable to different spatial scales. It can also be deterritorialized. A context can be about the global without comprising everything (think about functional international organizations). A global security community, even if conceived territorially, does not imply that every locality on earth must be a security community.

The crux of Deutsch et al.'s argument comes down to a simple point: the existence of the state is not a necessary or a sufficient condition for peace, nor is the non-existence of the state a necessary or a sufficient condition for the prevalence of the acute threat of political violence. These connections are contingent. The imposition of a common government, with its capability of violent enforcement of norms, may well decrease rather than increase the chances of peace. Besides claiming that there is no axiomatic relationship between the absence of state machinery of violence (or anything equivalent), and the condition of war, Deutsch and his associates tried to disprove the empirical hypothesis that the absence of a world state explains the recurrence of war.

In developing alternative and more processual hypotheses about the sources of war and peace, Deutsch et.al. distinguished between an amalgamated and pluralist security community. Deutsch conceived both as political communities, characterized by a process of political communication and the existence 
of some shared rules and practices. I have slightly modified Deutsch's definitions to make them more general:

Amalgamated community: A single governmental whole with a process of political communication, a single supreme decision-making centre, some machinery for enforcement, and practices of compliance.

Security community: A group of actors, which has become integrated:

- By integration is meant the attainment of a sense of community and of institutions and practices strong enough and widespread enough to assure, for a long time, dependable expectations of peaceful change among the members of the community.

- By sense of community is meant that there is a belief on the part of actors that they have to come to agreement on at least this one point: that common social problems can and must be resolved by processes of 'peaceful change'.

- By peaceful change is meant the resolution of social problems, normally by institutionalized procedures, without resorting to large-scale physical force.

A security community is one in which there is a real assurance that the members of that community will not fight each other physically, but will settle their disputes and conflicts in some peaceful way. If the entire globe were an integrated security community, wars and large-scale political violence would have mostly been eliminated (although an integrated whole in the above sense does not exclude categorically the possibility of violent intra-member conflicts). Amalgamated political communities may or may not be security communities, and vice versa. Thus, two types of security communities can be distinguished. Deutsch's well-known 2 x 2 conceptual scheme, presented schematically in table 7.1, is based on these distinctions. Examples in table 7.1 are references to historical cases, but these concepts can be applied to future possibilities at different spatial scales as well as non-territorially.

$<$ Table 7.1 about here $>$

Deutsch suggested twelve essential background conditions for an amalgamated security community to emerge and succeed. These include the mutual compatibility of main values; a distinctive way of life; capabilities and processes of cross-cutting communication; high geographic and social mobility; multiplicity and balance of transactions; a significant frequency of some interchange in group roles; a broadening of the political elite; and high political and administrative capabilities. They also include the willingness and ability of the majority of the politically relevant strata: (i) to accept and support common governmental institutions; (ii) to extend generalized political loyalty to them; (iii) and to operate these common institutions with adequate mutual attention and responsiveness to the messages and needs of all participating units. These are the most essential background conditions. Deutsch et al. 
claim that success is improbable in the absence of the essential conditions (Deutsch et al. 1957, pp. 1113). However, they also argue that these are not sufficient, for in any concrete context, other conditions may be - and typically are - needed as well. Moreover, 'we cannot assume that because conditions in one century led to certain effects, even roughly parallel conditions in another century would lead to similar effects' (Deutsch et al. 1957, p. 11). The implication of all this is that there are no timeless necessary and sufficient conditions.

Even if achieved, an amalgamated political community will remain contingent. It is vulnerable to strife, secession and civil war (Deutsch et al. 1957, pp. 29-31). Deutsch et al. argue that pluralistic security communities are easier to establish and maintain. Of the twelve conditions 'that appeared essential for the success of an amalgamated security community', only the compatibility of major political values, responsiveness to one another's messages and needs, and partial mutual predictability is required (Deutsch et al. 1957, p. 66).

The notion of security community is not only explanatory but can also be seen as a concrete (though generic) utopia, with the power to guide political practices (Deutsch et al. 1957, pp. 3-4, p. 7, pp. 1011). ${ }^{9}$ A concrete utopia involves lessons drawn from past or contemporary models; counterfactual reasoning about the possible effects of an altered context; as well as thought-experiments about the consequences of the transformed practices and systems. The future is uncertain and unintended consequences are ubiquitous. A concrete utopia may be based on anticipations that will turn out to be false. Thus concrete utopias must be open to revision on the basis of historical experiences.

\section{The emergence of common problems}

Common problems arise from shared processes. From 1450 to 1800, European expansionism brought the major regional economies in Asia, Africa, Europe and the Americas into increased contact (O'Brien and Williams 2016, ch. 3). The industrial revolution intensified these developments, sparking an 'indomitable surge toward a planetary economy' (Polanyi 1957, p. 89). Although not all processes can or should be reduced to political economy, global political economy forms a complex, dynamic mega-process, in which states and other actors are tightly interwoven and in which a large variety of issues arise. For instance, already the First World War indicated how the wide-scale application of industrial technology to warfare have given collective actors an unprecedented ability to harm one another. Modern security complexes can arise from various political economy processes also more directly (Adler and Barnett 1998; Chang 2016). The same is true of the causes of environmental problems. Transnational and global environmental problems, including climate change, are outcomes of the processes of industrialization and economic growth. 
Processes are open-ended and flowing, with one process capable of sliding into another, and with smaller processes combining to form larger processes. Entities such as states are not only products and manifestations of processes, but they also relational, and nearly all relevant relations concern political economy directly or indirectly. In the late $20^{\text {th }}$ and early $21^{\text {st }}$ century, the world economy has been grounded on cooperative institutional arrangements revolving around 'free trade' and related ideas, but its dynamics can generate contradictions and instigate conflicts. ${ }^{10}$ States' economic policies can be contradictory precisely because states are so closely interrelated and their fates so tightly intertwined in the liberal-capitalist world economy. Because of these contradictions, and for various historicalinstitutional reasons, states can be unable to solve common problems also in areas such as security and environment. The current 'gridlock of global governance', which is partly an unintended second-order effect of the liberal institution-building that followed World War II, is a dynamic process involving potential for further conflict escalation (see Hale, Held and Young 2013). ${ }^{11}$

States' attempts to be more 'competitive' or 'secure' than other states, or to have balanced budgets or ensure long-term fiscal sustainability, can result in self-defeating outcomes. The compositional fallacy occurs when it is assumed that what is possible for a single given actor at a given time is possible for all of them simultaneously. ${ }^{12}$ For instance, trade deficits and surpluses cancel each other out, so it is impossible that most states would be simultaneously running surpluses. Countries with trade surpluses tend to accumulate savings surpluses, whereas countries with trade deficits tend to accumulate debt, resulting in global imbalances. Therefore simultaneous attempts by all or most states to improve their trade balance tend be contradictory. The likely overall result is a reduction in effective aggregate demand in the world economy as a whole, affecting negatively most parts. Common institutions consider the cases of EMU and IMF - can be geared toward strengthening the contradiction. This in turn may lead to a spiral of responses that can aggravate the original problem, especially at the time of downturns and crises in the world economy. Short-sighted concerns over competitiveness can also override the potential for environmental cooperation.

Real world contradictions are not categorical because whether the contradicting forces cancel each other out - or whether one force in the end annuls the other - depends on contingent circumstances. It is possible for states to try to export their economic problems to other states by various means (e.g. through corporate tax competition), or even control exclusively conceived raw material sources and markets by imperial means, but if sufficient numbers of them attempt to do so simultaneously the result is a fallacy of composition, feeding conflicts among states and other actors. ${ }^{13}$ This kind of problem-generating process can by deepened by uncertainty about the future and by boom-and-bust cycles in finance (Kindleberger 2000; Minsky 2000). The financial crisis of 2008-2009 was the most serious crisis of the world economy since the 1930s and 1940s. This crisis almost produced a new great depression - the world economy verged on collapse in late 2008 and early 2009 - but automatic 
stabilizers, rescue and stimulus packages averted the worst. The global financial crisis nonetheless brought about a world-historical saddle point, inducing stasis and regression (Patomäki 2018, pp. 122128).

Moreover, differences in demand problems can result in uneven development - long-run growth divergences across countries or regions. This is because processes of uneven growth in the world economy involve not only vicious but also virtuous circles of cumulative causation. For instance, the Keynesian demand-led Kaldor-Verdoorn's effect may generate a virtuous circle between output and productivity growth (Kaldor 1966). Claims about the Kaldor-Verdoorn's effect were originally based on an empirical observation that in the long run productivity generally grows proportionally to the square root of output. Output can only grow if there is sufficient demand for the produced goods, so an increase in demand can lead to investments and higher productivity. ${ }^{14}$ Sustained uneven growth is likely to result in major imbalances in trade and finance, as can be seen for example from the USChina disputes over terms of trade and currency rates in the 2000s and 2010s.

Short-sighted and contradictory ways of responding to the existing and emerging problems of the world economy are both the cause and effect of those problems. The process tends to reinforce itself, partly because dynamics lead to political changes within and across states, often deepening and entrenching myopic self-regarding orientations. Many mechanisms can work toward this. For instance, volatile public opinion responds to changing conditions, shaping state and other responses toward a more myopic and self-regarding direction. Rising unemployment, widening social disparities and increasing uncertainty and dependence can generate existential insecurity among citizenry. Economic problems tend to threaten identity, as not only one's earnings but also one's social worth, rights and duties are tied to a position as an employee, entrepreneur or capitalist.

Economic problems can endanger social integration (Habermas 1988, pp. 20-31) and result in regressive ethico-political learning. Given characteristic difficulties and pathologies of socialization in a complex market society, and related crises of embodied personality, the blend of capitalist world markets and separate national states involve great potential for increasingly antagonistic social relations. For instance, the consequences of the global financial crisis of 2008-2009 and the subsequent Euro crisis heightened existential insecurities in Ukraine. Ukrainian GDP collapsed by almost $15 \%$ in 2009 , suddenly ending nearly a decade of economic growth and poverty-reduction. The drastic downturn also caused an acute financial crisis for the Ukrainian state. By 2013-14 the IMF and the EU demanded strict measures of austerity and extensive neoliberal reforms such as abolition of subsidies, deregulation and privatization, as well as measures against widespread corruption. Russia offered an alternative, less conditional loan. These developments provided the politico-economic context for the Euromaidan demonstrations and civil unrest in Ukraine. It was in this context that the 
conflict between Russia and the EU, NATO and US escalated. The point is not to argue for some sort of political economy determinism of outcomes. Most drastic turndowns or rises in unemployment or precariousness do not bring about revolutions or wars, but they do increase the proclivity to escalation of conflicts, and this proclivity may actualize if there are enough other forces and processes pushing developments in the same direction (Patomäki 2018, ch. 3).

The self-reinforcing negative dynamics of the world economy largely explain why the world has been reverting to nationalist statism, militarized conflicts and arms races. Especially in the 2010s, the international political environment has become less benign. An arms race may follow from (i) particular responses to economic problems and (ii) a related fallacy of composition. For instance, a state may decide to stimulate its economy by spending more on armaments (i.e. resort to military Keynesianism) and to keep a 'security margin' by trying to be better armed than its actual or potential military adversaries. If all relevant states - or even just two of them - try the same, the result can be an arms race, which may even escalate to war. ${ }^{15}$

The idea that common problems arise from shared processes can be expressed in still more general terms. Agents, structures and social relations change in the course of world history, not only through co-operation ${ }^{16}$ but also through absenting of absences, overcoming contradictions, and creating something new. ${ }^{17}$ This process is laden with potential for conflicts at various spatial scales and also in non-territorial social contexts (functional, identity-based etc). But geo-historical processes are also laden with potential for cooperation. A lot hinges upon the nature of common institutions. If the prevailing modes of agency and action and types of institutions enable the resolution of conflicts by means of peaceful changes - or, at the minimum, involve the reliable expectation that peaceful changes are possible if and when legitimate conditions are met - will minimize and possibly erase the threat of violence entirely.

\section{Overcoming contradictions through learning and building common institutions}

At the most general level, contradictions can arise from incorrect beliefs about how things work or from the lack of generalizability. Fallacy of composition is a typical but not the only form of social contradiction. For instance, contradictions can also occur at the level of social systems, if there are organizing principles that work against each other. The positive point is that contradictions can be overcome by means of collective action and by revising old or building new institutions. This overcoming involves learning and development of consciousness. Actors must first recognize that their environment consists of other similarly concerned and reflexive actors, all interwoven in the same problematic as 'we'. 
From a logical perspective we can analyse the learning process in terms of abstract stages of consciousness, as in Figure 7.2. In this scheme, the starting point is that actors take the environment as fixed in relation to their choices. When actors realize that others are actually facing the same situation, the problem of organizing collective actions may, in their minds, appear first as a strategic game. If the costs of initiating and organizing collective action seem high, instrumentally rational calculation shows no point in collaborating. Even if some activities were already being organized, many might still refrain from action in the belief of not being decisive for the outcome. This is the classic free riding or, with a higher level of consciousness, Prisoner's Dilemma (PD) situation, which in the world of myopic and self-regarding actors, can result in a collectively deficient outcome. ${ }^{18}$ Something more is needed.

\section{< Figure 7.2 about here >}

Hence, there is a contradiction specific to each moment of the learning process. Each contradiction has to be overcome before efficient collective action becomes possible. Trust and solidarity help to organize collective actions, but in any social system they not only depend on the prevailing modes of agency but are potentially subject to manipulation by the powerful actors. Communication is the first key and development of trust and solidarity the second key to the successful organization of collective action. In the past, communication often required frequent physical presence, but with the new technologies actors can communicate across space in real time much more easily. However, unless members of the contradiction-generating group come to know and trust each other on a face-to-face basis, 'it is hardly to be expected that they will be able to overcome the contradiction' (Elster 1978, p. 141).

The scheme of figure 7.2 can be analytically helpful, but if taken to imply that modes 1 and 2 are primordial, it is misleading. In complex societies with conscious actors, pre-existing social structures are conditions of possibility for agency and action. The parametric and strategic stages of consciousness of rational choice theory are best seen as products of geo-history, rather than as original states of the human mind. Trust, solidarity, long-term commitments and common institutions can be and to a degree must be - constitutive of the context in which actors are formed and socialized. The applications of rational choice theory and neoclassical economics to the social world may well impose a movement: mode $_{4} \rightarrow$ mode $_{3} \rightarrow$ mode $_{2} \rightarrow$ mode $_{1}$.

There are nonetheless geo-historical developments that seem to accord with the schematic movement from counterfinality to change. This movement can characterize also inter-state relations.

Contradictions of the world economy can be overcome by collective action and by building better common institutions. Collective actors such as states are complex social systems, however, and this 
can complicate the movement from counterfinality to change. Those acting in the name of a state occupy simultaneous positions at multiple sites of power and levels of organization. ${ }^{19}$

Consider the case of the Bretton Woods negotiations in 1944. Keynes analysed the source of the problem (a potential contradiction in trade policies) and convinced others about the counterfinal nature of orthodox economic policies. Keynes developed a design for an international clearing union. His idea was to create an impartial system for the management of currencies, and a world central bank responsible for a common world unit of currency, the bancor (Keynes 1942/1969, pp. 9-18; Keynes 1943/1969, pp. 19-36). Obligations would be made systemic, with financial positions defined against the rest of the world, not individual countries. Keynes also proposed mechanisms for transferring resources from surplus to deficit countries. The aim was to enable a 'new deal' everywhere.

The negotiations involved various intra-state and inter-state differences of opinion and conflicts. The outcome resembled Keynes's concrete utopia only in some regards. The 1944 Bretton Woods agreement did not include a world central bank or bancor or system of taxing the surplus. Over time, both the IMF and the World Bank started to apply structural adjustment policies to crisis countries. The burden of adjustment was shifted onto deficit countries, frequently resulting in deep recession, high social costs and further accumulation of debt. This amounts to imposing an obligation on weak and troubled states to follow contradictory economic policies.

Keynes's original proposal has been renewed and developed further by the Brandt Commission (Brandt 1980) and, more recently, by Paul Davidson (Davidson 1992-1993, 2002, 2004) and Joseph Stiglitz (Stiglitz 2006, pp. 245-268). ${ }^{20}$ What is important in this context is that variations among the proposed schemes - even in the camp of like-minded reformist thinkers who attempt to build trust, solidarity and commitments on a global scale - stem from differences not only in economic theory but also in ethical and political principles. This indicates that the setting up of new common institutions also involves ethico-political conflicts. The question is how to ensure that those conflicts are resolved peacefully.

\section{The self-transformative capacity of contexts}

There will always be disputes and conflicts among social forces. This implies that there can never be a stable 'order', an eternally fixed set of practices and institutions. Security communities are characterized by the expectation that future changes are going to be peaceful. Integration generates non-preparedness to use violence. This can be explicated as follows, in line with the ethical circle of non-violence (Patomäki 2002, ch. 8, especially pp. 200-202): 
A1. If a social system has become integrated, no relevant actor has any reasons to prepare for the use of political violence.

A2. As actors know (A1), they do not expect anybody to use political violence either to preserve the status quo or to foster changes.

B1. Non-preparedness becomes a generally followed and rarely, if ever, questioned rule of action.

B2. In the course of social time, (A2) becomes an automatic, routine-like and self-evident presupposition of political thought, argumentation and action.

A security community presupposes both (A1) and (A2). If the practical experience of actors confirms in the longer run (A1) and (A2), the security community becomes sedimented in the longue durée of social time, i.e. becomes institutionalized. (B1) and (B2) describe an institutionalized security community, such as the Nordic countries from, at the latest, the early 1950s onwards.

Are there any general conditions for the generation of (A1 and A2) and (B1 and B2), for the virtuous circle of the development of security community? The inner structures of actors, communication and learning are socially conditioned. For instance, the scope and diversity of the narratives and scenarios an actor is capable of generating is the result of past learning of shared cultural meanings and forms the basis for contemporary moral and strategic choices. However, available narratives also depend on the mechanisms of choice which select and amalgamate them. A system of domination can control or structure communication, and thereby shape not only available narratives, but also trust and loyalty between actors. Moreover, actors and actions are structured and stratified. Constitutive and regulative rules define and position an actor, who has stratified and structured reasons for her actions that occur in the context of unintended consequences of action. Reified and naturalized, hierarchical or heteronomic relations of domination may sustain particular practices and related patterns of practical reasoning and rationalization.

According to Roberto Unger, it is possible to change not only the content but also the force of social contexts (Unger 1987a, pp. 35-36, 277-312; 1987b, pp. 155-157). By force of contexts is meant their relative immunity to challenge in the midst of everyday practices, the rigidity of positions of their positioned practices, and the consequent rigidity of social division and hierarchy. Social contexts can be distinguished with respect to their openness to transformation. Unger refer to this openness as the 'negative capability', but I think the term self-transformative capability of contexts describes the idea better. It means the facility to challenge the context in the midst of everyday practices and the disengagement of actors' 'practical and passionate dealings from a pre-existing structure of roles and hierarchies' (Unger 1987a, pp. 278-279 [note 40]). Since only agents in social relations can carry out context-transformations and since this is social activity, the conditions for individual self- 
transcendence and collective context-transformation are embedded in the context. On the basis of this reasoning, a general hypothesis emerges, according to which it is the self-transformative capability of contexts that determines the possibilities for a pluralist and amalgamated security community. Therefore, the expectation of peaceful changes should be higher in the more self-transformative contexts.

To put it as simply as possible, contexts differ in their openness to change, and this is crucial for the emergence and maintenance of a security community. The question thus emerges, to what extent do the relevant rules and relations have self-transformative capacity? One indicator is whether preparations are being made for violence against (potentially) deviant or context-challenging groups or states within the global community. It also matters whether actors categorize themselves as parts of a wider whole. Among the relevant actors, is there a shared belief in the existence of a larger community? A security community may require agreement on a number of things, and may lead to collective identity-formation. Any sense of community can, however, develop and harden into a will that expects others to comply.

The preparedness to use violence is typically based on the necessitarian assumption about the unchangeable essence of both oneself (members of community) and others (outsiders). Manichean conceptions make a strict distinction between us and them. Manicheanism is constituted by a dichotomy of good vs. evil and an epic story about a struggle between the forces of light and darkness. Violence against evil is often seen as justified (Harle 2000, pp. 48-52 et passim). When a conflict escalates, a Manichean dichotomy can lead to the idea that evil must be eliminated. A less extreme aim is to teach 'them' lessons by

< Figure 7.3 about here >

means of sanctions and painful experiences. When fear of the dark other dominates, actors can resort to repression or deterrence against norm-violators. Military deterrence also relies on essentialist assumptions: practitioners of military deterrence have a propensity to presuppose that the other is likely to attack and conquer if given a chance. By increasing the cost of attack, it can be made less likely. These kinds of assumptions are not generalizable due to a fallacy of composition. When both sides resort to suspicion and deterrence, the likely outcome is a spiral of conflict. ${ }^{21}$

The self-transformative capacity of contexts is not compatible with illusions and mystifications about, or reifications and naturalizations of others, or of social realities more generally. Conversely, the denaturalization of understandings can contribute to the openness and responsiveness of the community. The ethical circle of non-violence of figure 7.1 includes the idea that actions shape agents 
and norms. It is one of the key tasks of human sciences to make contexts more open to revision (which does not mean that all changes are justified). Figure 7.3 situates critical social sciences in the complex that is capable of generating a security community, emphasizing the role of knowledge. Generation of a security community is also an educational process.

First, there is the definition of a security community. A security community consists of geo-historical social systems in which actors do not prepare for the use of organized violence against each other. Mere separate indifference is not enough for a community - there must be some real interconnectedness of elements of the systems. Integration generates the non-preparedness for the use of political violence. Integration consists of sense of community and expectation of peaceful changes. Critical social scientific explanations works for enhancing the self-transformative capability of contexts by criticizing untrue naturalizations, reifications and fetishations of social being and related mystifications of knowledge; by making arguments for peaceful transformations; and by creating mechanisms of reflective learning. Modes of agency are a key component of social contexts.

To reiterate, a lot depends on how identities and modes of agency are constructed. The demystification and denaturalization of understandings can contribute to openness and responsiveness through transforming prevailing modes of agency and constitution of actor-identities. In the desecularized world of the early twenty-first century (Berger 1999), an important aspect of ethico-political identity concerns religion. The world religions that were born during the axial age between 800 and $200 \mathrm{BCE}$ and became dominant in the course of the first millennium ACE try to respond to the deep existential and moral questions that emerged during this period. ${ }^{22}$ The problem is that these world religions tend to generate a hardened will among some of their adherents.

Abrahamic religions have repeatedly been interpreted as well as perpetrated as Manichean. Also other axial world religions have shown a lot of potential for antagonistic self-other relations and violence even Buddhism, which is often thought to be the most peaceful of religions. ${ }^{23}$ It is not religion in isolation that generates violence. Rather social processes can activate the inner structures of religious systems, shape religious meanings and practices, and provide justifications for struggles that originate elsewhere. For instance, neoliberal globalization has prompted developments toward religious intolerance and hard will. ${ }^{24}$ There is no simple automatic logic or deterministic law according to which monotheism - or religion more generally - must lead to intolerance, repression and violence. Religion can just as well underlie pacifism and tolerance or pluralism. ${ }^{25}$ And notably, modern scientism can also be Manichean insofar as it tends to juxtapose religious violence against secular rationality. In the early twenty-first century, this form of Manicheanism is most typically antagonistic toward political Islam. ${ }^{26}$ 
A lot hinges upon epistemology: how certain are actors about beliefs and stories constituting their group identities and interests? A belief in literal and necessary truths, whether revealed in sacred texts or by reductionist theories of modern science, is liable to constitute a hardened will (Reitan 2009, pp. 210-220). It is, however, possible to combine ontological realism about god and divinity with epistemological relativism. The latter implies that god or divinity can manifest itself in a variety of ways; and is accessed by different people in different traditions in a plurality of ways. ${ }^{27}$ 'Obviously once you accept epistemological relativism you must accept tolerance and pluralism' (Bhaskar 2012, p. 32).

Relativism does not mean that we cannot have better or worse grounds for adopting some particular god-oriented beliefs or spiritual practice. Our claims to knowledge of god are fallible, like anything else. While any hypothesis about god or divinity can fail, it does not mean that they all must fail. Globalization in the deeper sense, as a coming-together of humanity, requires an open-ended dialogue about the fundamentals, including in terms of religion (whatever forms it may assume). This dialogue has ethico-political implications, for giving a voice to others is not neutral; dialogue entails recognition of equality and corresponding institutions (Patomäki 2003). Dialogical, planetary religions and philosophies thus accord with the notion of a global 'democracy-to-come' (Derrida 1992, pp. 3542, pp. 76-83). ${ }^{28}$ Resultant forms of religion are unlikely to cultivate anthropomorphic conceptions of god and more likely see divinity in the mystery of being and in the processes of cosmic evolution, of which we humans are a part.

Religion is only one possible source of identity-constituting differences. A variety of causal processes can accentuate language-based differences into intensely and perhaps violently negative self-other relations. The generation of a security community (figure 7.3) requires explanations of these causal processes, characteristically in terms of political economy, and critical understandings of the underlying logic of differences (Patomäki 2017b). At a deep level, criticisms may also concern, say, the alienation and oppression characteristic of the capitalist market economy (Bhaskar 1986, p. 194).

A key problem in the early twenty-first century is that the presently prevailing market globalism can acknowledge neither the role of identity-constituting differences nor the significance of socioeconomic privileges. This is one of the key reasons why the concerns and anxieties of everyday life are nowadays so often mobilized for antagonistic politics, mostly in terms of frames, categories, metaphors and myths that have been sedimented into the deep structures of national and/or religious imaginary.

\section{Concluding remarks: a few qualifications}


All social relations, practices and institutions can be revised. Common institutions can be built to overcome prevailing contradictions. It is one of the tasks of social sciences to propose concrete utopias, which must be consistent with the ethical circle of non-violence (figure 7.1) and with processes generating and sustaining security community within the relevant context (figure 7.3 ). The more capable common institutions are, the more amalgamated the community.

Global context is not the only context that matters, but global dynamics tend to shape developments in local contexts too. The conditions for collective context-transformation are thus not only local, national or regional but also global, and in many areas increasingly so. It is thus important to revise the existing and construct new global institutions in order to tackle common problems in an adequate way. The revised and new institutions should be more open to differences and revision than what the postWWII institutions have been. Self-transformative capacity generates dependable expectation of peaceful changes and qualifies the sense of community, fostering malleable, tolerant and pluralist group-identities (assuming sufficient socio-economic security, fair absence of privileges, and other contextual factors).

Characteristically, the opening up of various global contexts for peaceful changes - for increasing their self-transformative capacity - amounts to global democratization. And yet the two are not synonymous. While democratization and the development of security community are often mutually supportive, this is not always the case. Since the development of a security community is a long and complicated process of institutionalization of mutual acceptance, trust and procedures and practices of peaceful change, and since it is always vulnerable to escalation of conflicts, an unthinking attempt at global democratization may eventually be counterproductive. Steps toward amalgamation, while needed, increase the risks of counterproductivity.

A Eurocentric and closed model of democracy, based on a linear conception of time and progress, has the potential to justify exclusions and repression - particularly in contexts characterized by insecurities and privileges. A rigid model of global democracy may similarly contribute to escalation of violence rather than to global democratization..$^{29}$ Ethico-political judgements must always be context-sensitive and take seriously the consequences of uncertainty and openness of geo-historical processes. Moreover, democracy is best conceived not as a fixed model of any sort, but as an open-ended and continuous process.

\section{References}

Adler, E., \& Barnett, M. (Eds.) (1998). Security communities. Cambridge: Cambridge University Press. 
Allansson, M., Melander, E., \& Themnér, L. (2017). Organized violence, 1989-2016. Journal of Peace Research, 54(4), 574-587.

Amadae, S. (2015). Prisoners of reason. Game theory and neoliberal political economy. Cambridge: Cambridge University Press.

Berger, P.L. (Ed.) (1999). The desecularisation of the world. Resurgent religion and world politics. Grand Rapids, MI: William B. Eerdmans.

Bhaskar, R. (1986). Scientific realism and human emancipation. London: Verso.

Bhaskar, R. (1993). Dialectic: the pulse of freedom. London: Verso.

Bhaskar, R. (2000). From east to west: odyssey of a soul. London: Routledge.

Bhaskar, R. (2012). From science to emancipation. Alienation and the actuality of enlightenment. London \& New York: Routledge.

Bloch, E. ([1954, 1955, 1959] 1986). The principle of hope. London: MIT Press.

Brandt, W. (1980). North-South: a programme for survival: the report of the independent commission on international development issues under the chairmanship of Willy Brandt. London: Pan Books.

Ceadel, M. (1987). Thinking about peace and war. Oxford: Oxford University Press.

Chang, J.Y. (2016). Essence of security communities: explaining ASEAN. International Relations of the Asia-Pacific, 16(3), 335-369.

Davidson, P. (1992-1993). Reforming the world's money', Journal of Post Keynesian Economics, 15(2), 153-79.

Davidson, P. (2002). Financial markets, money and the real world. Cheltenham: Edward Elgar.

Davidson, P. (2004). The future of the international financial system. Journal of Post Keynesian Economics, 26(4), 591-605.

Derrida, J. (1992). The other heading: reflections on today's Europe, trans. P.-A. Brault \& M.B. Naas. Bloomington: Indiana University Press.

Deutsch, K.W., Burrell, S.A., Kann, R.A., Lee Jr., M., Lichterman, M., Lindgren, R.E., Loewenheim, F.L., \& Van Wagenen, R.W. (1957). Political community and the North Atlantic area. International organization in the light of historical experience. Princeton, NJ: Princeton University.

Elster, J. (1978). Logic and society: contradictions and possible worlds. Chichester: John Wiley \& Sons.

Gates, S., Nygård, H.M., Strand, H., \& Urdal, H. (2016). Trends in armed conflict, 1946-2014. PRIO Conflict Trends 1. https://www.prio.org/Publications/Publication/?x=8937. Accessed date.

Giddens, A. (1994). Beyond left and right. The future of radical politics. Cambridge: Polity.

Greenwald, B., \& Stiglitz, J.E. (2010). Towards a new global reserve system. Journal of Globalization and Development, 1(2), 1-24.

Habermas, J. (1988). Legitimation crisis, trans. by T. McCarthy. Cambridge: Polity Press. 
Hale, T., Held, D., \& Young, K. (2013). Gridlock: why global cooperation is failing when we need it most. Cambridge: Polity Press.

Harle, V. (2000). The enemy with a thousand faces. The tradition of the other in Western political thought and history. Westport, CT: Praeger.

Held, D., \& Patomäki, H. (2006). Problems of global democracy: a dialogue. Theory, Culture \& Society, 23(5), 115-133.

Jaspers, K. (1953). The origin and goal of history, trans. by M. Bullock. London: Routledge and Kegan Paul.

Jervis, R. (1976). Perception and misperception in international politics. Princeton, NJ: Princeton University Press.

Jessop, B. (2012). Obstacles to a world state in the shadow of the world market. Cooperation \& Conflict, 47(2), 200-219.

Kaldor, N. (1966). Causes of the slow growth in the United Kingdom. Cambridge: Cambridge University Press: Cambridge.

Keynes, J.M. (1937). The general theory of employment. The Quarterly Journal of Economics, 29(1), $1-17$.

Keynes, J.M. (1942/1969). Proposals for an international currency (or clearing) union [February 11 1942]. In J. Horsefield (Ed.), The International Monetary Fund 1945-1965: twenty years of international monetary cooperation, Volume 3. Washington, DC: International Monetary Fund.

Keynes, J.M. (1943/1969). Proposals for an international currency (or clearing) union [April 1943]. In J. Horsefield (Ed.), The International Monetary Fund 1945-1965: twenty years of international monetary cooperation, Volume 3. Washington, DC: International Monetary Fund.

Kindleberger, C. (2000). Manias, panics, and crashes: a history of financial crises (4th edition). New York: John Wiley \& Sons.

Lawson, T. (1997). Economics \& reality. London: Routledge.

Lijphart, A. (1981). Karl W. Deutsch and the new paradigm in international relations. In R. Merritt \& B. Russett (Eds.), From national development to global community. Essays in honour of Karl. W. Deutsch (pp. 233-251). Boston: Allen and Unwin.

Markwell, D. (2006). John Maynard Keynes and international relations: economic paths to peace. Oxford: Oxford University Press.

Minsky, H. (2008). Stabilizing an unstable economy. New York: McGraw Hill.

O'Brien, R., \& Williams, M. (2016). Global political economy: evolution and dynamics, revised and up-dated 5 ed. London: Palgrave MacMillan.

Osborne, S. (2016, May 30). Richard Dawkins responds to the suggestion atheists are violent. The Independent. https://www.independent.co.uk/news/people/richard-dawkins-responds-to-thesuggestion-atheists-are-violent-a7056301.html. Accessed 15 October 2018. 
Patomäki, H. (2001). The challenge of critical theories: peace research at the start of the new century. Appendix: realist ontology and the possibility of emancipatory social science. Journal of Peace Research, 38(6). https://www.prio.org/JPR/Datasets/\#2001. Accessed 15 October 2018.

Patomäki, H. (2002). After international relations. Critical realism and the (re)construction of world politics. London: Routledge.

Patomäki, H. (2003). From east to west: emergent global philosophies - beginnings of the end of the Western dominance? Theory, Culture \& Society, 19(3), 89-111.

Patomäki, H. (2008). The political economy of global security. War, future crises and changes in global governance. London and New York: Routledge.

Patomäki, H. (2013). The great Eurozone disaster. From crisis to global new deal. London: Zed Books.

Patomäki, H. (2016). International political economy and security. In T. Balzacq \& M. Dunn Cavelty (Eds.), The Routledge handbook of security studies (2nd edition). London: Routledge.

Patomäki, H. (2017a). Praxis, politics and the future: a dialectical critical realist account of worldhistorical causation. Journal of International Relations and Development, 20(4), 805-825.

Patomäki, H. (2017b).On the possibility of a global political community: the enigma of 'small local differences' within humanity. Protosociology. An International Journal of Interdisciplinary Research, 33, 93-127.

Patomäki, H. (2018). Disintegrative tendencies in global political economy: exits and conflicts. London and New York: Routledge.

Pinker, S. (2011). The better angels of our nature: the decline of violence in history and its causes. London: Allen Lane.

Polanyi, K. (1957). The great transformation. The political and economic origins of our time. Boston, MA: Beacon Press (orig. published 1944).

Putnam, R. (1988). Diplomacy and domestic politics: the logic of two-level games. International Organization, 42(3), 427-460.

Rapoport, A. (1960). Fights, games and debates. Ann Arbor: University of Michigan Press.

Reitan, E. (2009). Is God a delusion? A reply to religion's cultured despisers. Oxford: WileyBlackwell.

Rescher, N. (1977). Dialectics. A controversy oriented approach to the theory of knowledge. New York: State University of New York Press.

Rescher, N. (1996). Process metaphysics. An introduction to process philosophy. New York: State University of New York Press.

Rescher, N. (2006). Philosophical dialectics. An essay on metaphilosophy. New York: State University of New York Press.

Ruthven, M. (2007). Fundamentalism. A very short introduction. Oxford: Oxford University Press.

Stiglitz, J.E. (2006). Making globalization work: the next steps to global justice. London: Allen Lane. 
Unger, R.M. (1987a). False necessity. Anti-necessitarian social theory in the service of the radial democracy. Cambridge: Cambridge University Press.

Unger, R.M. (1987b). Social theory: its situation and its task. Cambridge: Cambridge University

Press.

\footnotetext{
${ }^{1}$ For different meanings of uncertainty, including epistemological \& ontological chance and openness of social systems \& reflexivity of anticipations, see Patomäki (2017a).

${ }^{2}$ A well-known collection is Adler and Barnett (1998); whereas an example of a rather critical application is Chang (2016).

${ }^{3}$ This is a key theme of my books Patomäki (2008); and Patomäki (2018).

${ }^{4}$ In the 1970s, philosophers such as J.L.Mackie, Rom Harré and Roy Bhaskar developed complex realist
} accounts of causation. For a concise summary of the relevance and consequences of the distinction between open and closed system, see the 'Appendix: Realist Ontology and the Possibility of Emancipatory Social Science' to my 2001 Journal of Peace Research. The notion of contrastive demi-regularity has been developed by Lawson (1997, pp. 204-213).

${ }^{5}$ Ernst Bloch introduced the concept of concrete utopia in his The Principle of Hope that was published successively in three volumes in 1954, 1955, and 1959. The term has been adopted by various critical theorists, including Bhaskar (1993, p. 286, p. 297). The term u-topia is a bit misleading, as it means a place nowhere. A positive, hope-inspiring counterpart to dystopia is actually eutopia, which could be translated as 'a good place' (or: a place enabling human flourishing).

${ }^{6}$ However, the dramatic increase in the number of fatalities in organized violence, seen between 2011 and 2014, did not continue in 2015 and 2016. See Allansson, Melander and Themnér (2017).

${ }^{7}$ For an excellent summary and discussion, see Lijphart (1981).

${ }^{8}$ Moreover, ample evidence suggests that overall violence and war in human society has been declining for centuries (notably violent deaths per annum relative to population). This thesis is now often associated with Pinker (2011).

${ }^{9}$ Deutsch et al. do not use the terminology of concrete utopia.

${ }^{10}$ I discuss the problems of free trade based theories of peace in Patomäki (2016, pp. 32-42). There is no space here to discuss the decisive role of increasing income and wealth inequalities in the world system, but see Patomäki (2018), especially ch. 5.

${ }^{11}$ Hale, Held and Young (2013) explain the current obstacles to developing global governance further by referring to various second-order effects such as institutional inertia, fragmentation, and harder problems (extensity: scope of problems has increased; intensity: problems penetrate more deeply into societies). They also discuss the effects of growing multipolarity. What they lack is a systematic analysis of the contradictions of global political economy.

${ }^{12}$ For a general philosophical account of the fallacies of composition and division, see Rescher (2006, ch. 5); for an analytical social-theoretical account, see Elster (1978, pp. 97-106); and as applied to economic theory and global political economy, Patomäki (2013, chs. 2 and 8).

${ }^{13}$ This is what J.M. Keynes realized already during the Versailles negotiations and developed more systematically during the World War II. For an excellent exposition, see Markwell (2006).

${ }^{14}$ This is also because investments depend on fluctuations of uncertainty that are directly linked to effective total demand; for a first systematic articulation of this claim, see Keynes (1937).

${ }^{15}$ For Richardson's explosive arms race model, where parties seek a 'security margin', see Rapoport (1960, pp. 15-30). Robert Jervis's Spiral Model is more sophisticated, since it explicitly incorporates misperceptions, selffulfilling prophecies, lessons drawn from history etc. Jervis (1976, pp. 62-82 et passim).

${ }^{16}$ The taken-for-granted background assumptions of any social situation - including those rare situations that are violently conflictual - involve numerous ties of cooperation. The modern world society is based on such deep interdependence and division of labour that our everyday lives form a worldwide cooperative system.

${ }^{17}$ This terminology may be closer to Bhaskar than Rescher, but here I synthesize the two. See especially Rescher (1996); Rescher (1977); and Bhaskar (1993).

${ }^{18}$ This account is in essence, from a critical realist perspective, a summary of Elster (1978, ch. 5). I first attempted to apply this scheme to world politics in Patomäki (2008, pp. 198-200). I agree with Sonja Amadae (2015), however, that game theory is best seen as constitutive of state practices rather than as their external explanation; yet it can be applied in historical-constructivist explanations.

${ }^{19}$ One very well-known articulation of this idea is that of Putnam (1988); a more structurally oriented perspective is provided by Jessop (2012). 
${ }^{20}$ This model was originally developed in an earlier edition of Greenwald and (2010).

${ }^{21}$ A classic exposition of this problematic is Jervis (1976, esp. ch. 3, pp. 58-115). Jervis maintains that although modern adolf hitlers are rare, some agents may in some historical contexts be likely to attack and conquer.

22 'What is new about this [axial] age, in all three areas of the world, is that man becomes conscious of Being as a whole, of himself and his limitations. He experiences the terror of the world and his own powerlessness. He asks radical questions. Face to face with the void he strives for liberation and redemption.' Jaspers (1953, p. 2).

${ }^{23}$ For a simple but informative overview of the latent and actual 'fundamentalism' of all world religions, see Ruthven (2007, on Buddhism e.g. p.104).

24 '[D]efence of tradition only tends to take on the shrill tone it assumes today in the context of detraditionalization, globalization and diasporic cultural exchanges. [...] This is why fundamentalist positions can arise even in religions (like Hinduism and Buddhism) which have hitherto been very ecumenical and tolerant of other beliefs.' Giddens (1994, p. 85). For an account about how neoliberal economic policies tend to generate existential insecurities encouraging moves of securitization and negative other-building, see Patomäki (2018).

${ }^{25}$ A contribution to the complex ongoing debate, arguing that faith in god can be consistent with reason and morally benign, is Reitan (2009).

${ }^{26}$ This is typically a second-order form of Manicheanism, becoming Manichean by way of accusing especially Abrahamic religions of Manicheanism: 'Christianity used to be the most dangerous religion. Now Islam is.'

Richard Dawkins in an interview by Samuel Osborne: 'Richard Dawkins responds to the suggestion atheists are violent' (Osborne 2016).

${ }^{27}$ Ontological realism, epistemological relativism and judgmental rationalism, as applied to religion; see Bhaskar (2000, e.g. p. 20, 89).

${ }^{28}$ Any contemporary specification of rights or democracy also excludes and, thereby, tends to be violent. For Jacques Derrida, the democracy-to-come recognizes this aporia and thereby opens itself up to the possibility of further transformations, to taking up other directions, to becoming its other, also by means of dialogue and interactions with concrete others at any point in time.

${ }^{29}$ For a critical discussion over this problematic, see Held and Patomäki (2006). 
Figure 7.1: The ethical circle of non-violence (pacific-ism)

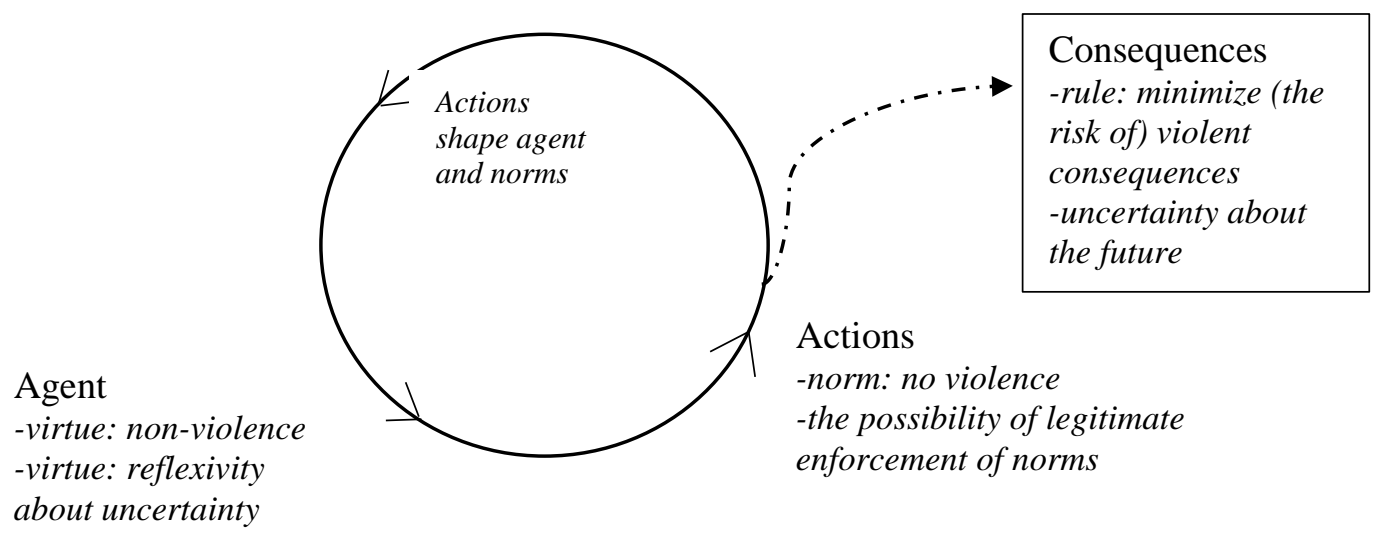

Source: Developed from the ethical circle of Bhaskar (1993, p. 248).

Table 7.1. Amalgamation and integration

\begin{tabular}{|c|c|c|}
\hline & Non-amalgamation & Amalgamation \\
\hline Integration & $\begin{array}{l}\text { Pluralistic security- } \\
\text { community } \\
\text { examples } \\
\text { Norden, the EU, Canada-US, } \\
\text { South-East Asia (?) }\end{array}$ & $\begin{array}{l}\text { Amalgamated security- } \\
\text { community } \\
\text { examples } \\
\text { Most OECD countries, } \\
\text { China }\end{array}$ \\
\hline Non-integration & $\begin{array}{l}\text { Not amalgamated, not } \\
\text { security community } \\
\text { examples } \\
\text { US-SU during the Cold War } \\
\text { India-Pakistan, US-'rogue } \\
\text { states', US-China }\end{array}$ & $\begin{array}{l}\text { Amalgamated but not } \\
\text { security community } \\
\text { examples } \\
\text { Habsburg Empire } 1914 \\
\text { Yugoslavia 1975-2000 } \\
\text { Syria before the civil war }\end{array}$ \\
\hline
\end{tabular}


Figure 7.2: From counterfinality to social and political change

Mode $_{1}$ : parametric consciousness (environment is fixed in relation to his choice) -problem of providing public good
Mode $_{3}$ : realization of

the contradiction at

the level of the whole

$\rightarrow$ attempts to organize collective action

-still subject to free riding \& strategic considerations
Mode $_{4}$ : attempts to build trust, solidarity and commitments $\rightarrow$ common institutions

-success depends on agency and sociohistorical conditions
Mode $_{2}:$ strategic

consciousness

(anticipation of the moves of others)

-strategic game (PD) 
Figure 7.3: Generation of a security community

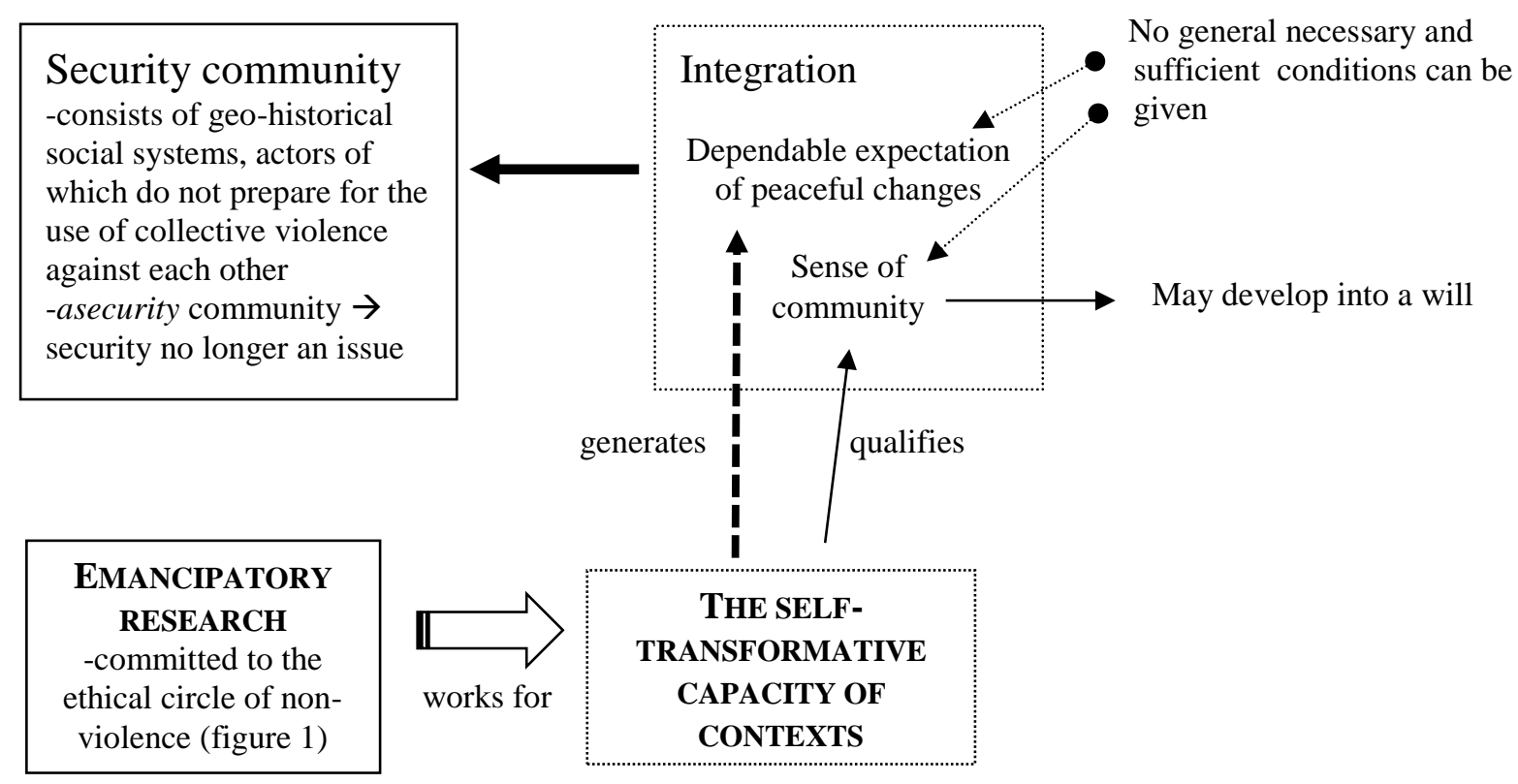

Source: Modified from Patomäki (2002, p. 204). 